\title{
Rare Case Report of Bilateral Pigmented Lesion on Alae of Nose
}

\author{
Dr.Anjana ${ }^{1}$, Dr.Smitagupta ${ }^{2}$, Dr.K.P.Sinha ${ }^{3}$, Dr.Anant Sinha ${ }^{4}$ \\ ${ }^{I}$ Ex.Resident,Deptt.Of Pathology,RIMS,Ranchi \\ ${ }^{2}$ Tutor, Deptt.Of Pathology,RIMS,Ranchi \\ ${ }^{3}$ Associate Proff. Deptt.Of Pathology,RIMS,Ranchi \\ ${ }^{4}$ Plastic Surgeon,Devkamal Hospital,Ranchi
}

\begin{abstract}
Basal cell carcinoma is most common skin cancer caused by prolonged exposure to ultraviolet rays.It is also called as rodent ulcer. It primarily affects individual with light eyes, hair and fair complexion but pigmented basal cell carcinoma has predilection for darker skinned population with dark brown eyes.Usually it presents as pigmented nodular mass over nose or malar region.It grows in slow and indolent fashion.Treatment of choice is surgical excision with $2 \mathrm{~mm}$ of margin.Here we report a case of bilateral pigmented lesion on alae portion of nose.
\end{abstract}

Keywords: Basal cell carcinoma,Pigmented basal cell carcinoma,Ultraviolet radiation

\section{Introduction}

Basal cell carcinoma is neoplasm of basal keratinocytes and is most common human malignancy, accounting for estimated $80 \%$ of skin cancer ${ }^{1}$.Most often it occurs on sun exposed area,particularly on face of white skinned adults but can occur at any cutaneous site and any race.It can also develop in sunlight protected skin,in lower leg associated with chronic venous stasis,over AV malformation,Xray exposure. There are many subtypes of basal cell carcinoma including superficial nodular,infiltrative and pigmented type ${ }^{2}$.Approx.7\% of basal cell carcinoma are pigmented.Pigmented variant of BCC is characterised by irregurarly pigmented,well marginated nodule with telengiactic vessel on its surface.Centre may be depressed or ulcerative ${ }^{3}$.Colour varies from light brown to dark black..The tumor may ressemble a malignant melanoma.It grows in indolent fashion but rarely metastasize.BCC is cured by simple excision but if untreated,tumor may invade subcutaneous fat,skeletal muscles,bone and become recalcitrant to excision.

\section{Case report}

A $51 \mathrm{yr}$ old male with dark complexion presented with pigmented mass on alae of nose bilaterally for last 5yrs. He had no complain of fever or pain.On examination,pigmented mass was present on ala of nose of size $3 \mathrm{~cm} \times 2 \mathrm{~cm}$ with irregular margin,firm in consistency,non tender and fixed to skin.Histopathological examination of tissue is done which shows island of basaloid cells with peripheral palisading surrounded by retraction artifacts. Also pigments in stroma as well as in island of cells.

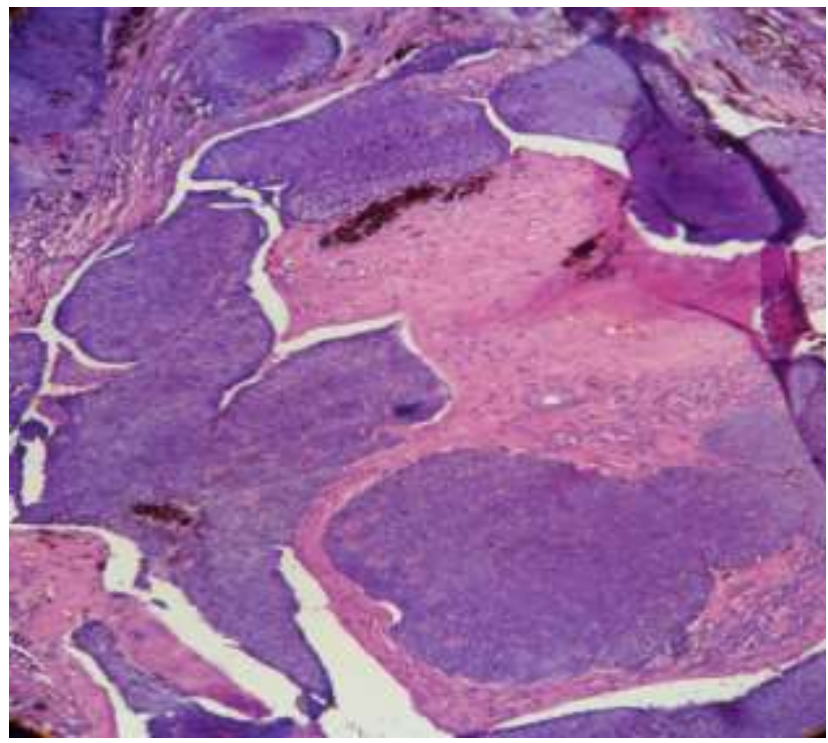

Figure 1- tumour shows island of of cells with pigments in island and stroma ( $H \& E \times 20)$ 


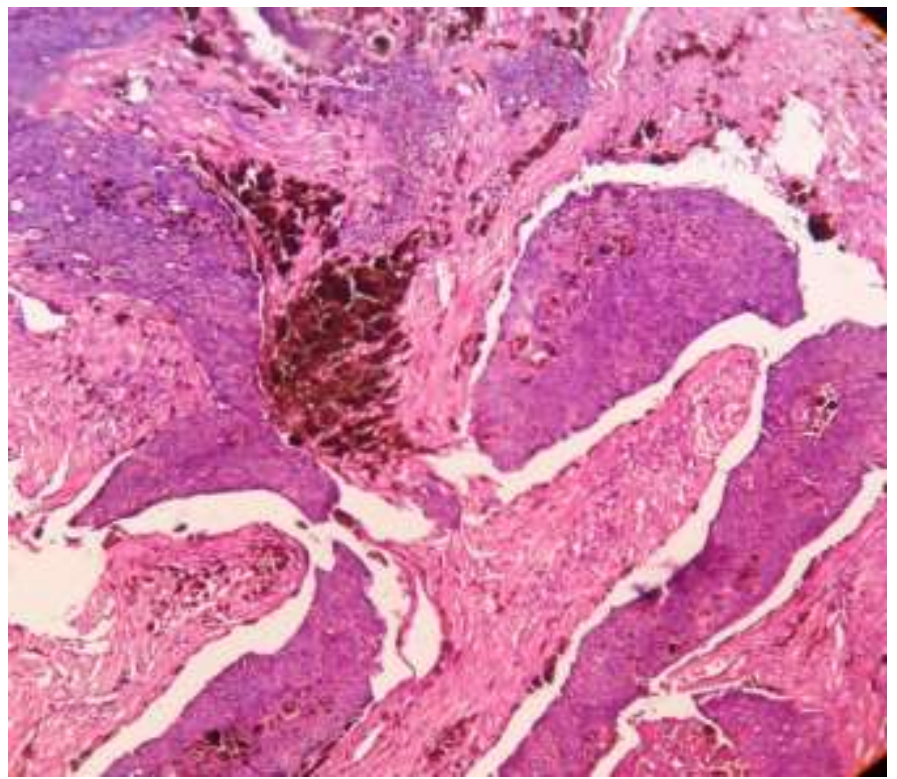

Figure 2- tumour shows island of of cells with pigments in island and stroma ( H\&E x40)

\section{Discussion}

Jacob Arthur in Dublin in 1827 first coined the term "rodent ulcer"to describe basal cell carcinoma.BCC comprises $65 \%$ of all malignant skin tumor and $80 \%$ of non-melanoma cancer ${ }^{4}$.It occurs mostly in fourth decade of life or later but also reported in younger patients with male:female ratio 3:2.Combination of environmentl factors,phenotype and genetic predisposition are the main aetiological factors ${ }^{5}$.Among environmental factors, intermittent U.V radiation exposure is most important risk factor and other less important are exposure to ionising radiation,arsenic and coal $\operatorname{tar}^{6}$. Bart RS et al also noted that pigmented BCC is more common in dark eyed people and very rare in blue eyed people.There are many subtypes of BCC like nodular,superficial,spreading,pigmented,cystic,micronodular,morphea form and infiltrating,of which nodular form is most common ${ }^{7}$.According to study done by RoKW et al,pigmented BCC shows lesser subclinical infiltration than nonpigmented BCC.Pigmentation can be found indifferent clinical variant of BCC but vary in colour depending on no. of melanocytes and amount of melanin present within tumor.HMB45 and S100 currently two most useful immunomarker to identify melanocytes and melanoma.Differential diagnosis for pigmented BCC include pigmented naevus,melamoma,pigmented seborrheic keratosis and pigmented Bowens disease ${ }^{8}$.

Histology shows nest of basaloid cells with peripheral palisading,abundance of melanin and melanophages and moderate inflammatory infiltrate.The melanocytes are located among tumor nests, while the melanophage are present in the stroma.Increased awareness is required in Indian population particularly with more outdoor activities.Our patient is 52 yrs old male presented with pigmented mass over ala of nose bilaterally.Any pigmented lesion need to be observed for increase in size.Treatment of choice in PBCC is surgical excision but for more aggressive BCC Mohs Microscopic Surgery is recommended.Intralesional injection of interferon alpha is an alternative treatment option.

\section{Conclusion}

$\mathrm{BCC}$ is the most common nonmelanoma skin cancer in the world.Pigmented BCC is rare,but it is becoming increasingly common in Asian population due to exposure to UV radiation.It is commonly treated as benign naevus by most general physician so clinical suspicion is important in case of pigmented lesion.Therefore patient should be educated and reinforced about this malignancy so that patient survival can be increased.

\section{References}

[1]. Urbach F. Incidence of non melanoma skin cancer. Dermatol Clin 1991;9:751-55.

[2]. Dourmishev A, Popova L, Dourmishev L. Basalcell carcinoma and squamous cell carcinomas: Epidemiology, location and radiotherapy.Skin Cancer 1996;11:195-200.

[3]. Telfer NR, Colver GB, Bowers PW. Guidelines for the management of basal cell carcinoma. Br J Dermatol. 1999;141(3):415-23

[4]. Dourmishev LA, Rusinova D, Botev I. Clinical variants, stages, and management of basal cell carcinoma. Indian Dermatol Online J 2013;4:1217

[5]. White EA, Rabinovitz HS, Greene SR, Oliviero M, Kopf A. Pigmented Basal Cell Carcinoma Simulating Melanoma in a Burn Scar .Cutis 404-06 
[6]. Janjua OS, Qureshi SM. Basal cell carcinoma of the head and neck region: An analysis of 171 cases. J of Skin Cancer 2012;2012:943472

Zabbia G, Gulotta E, Clemente D, Napoli P, Tripoli M, Corradino B, et al. Basal Cell Carcinoma Arisen on Rhinophyma: Report of Four Cases. Journal of Case Reports 2013;3(2):299-303

[7]. Markey AC, Lane EB, Macdonald DM, Leigh IM. Keratin expression in basal cell carcinoma. Br. J Dermatol 1992; 126 (2): 15460 .

9. Nouri K, Ballard CJ, Patel AR, Brasie RA. Basal Cell Carcinoma. In: Nouri K,editor. Skin cancer. New York: Mc Graw Hill. 2007; 61-85

[8]. Misago N, Suzuki Y, Miura Y, Narisawa Y. Giant polypoid basal cell carcinoma with features of fibroepithelioma of Pinkus and extensive cornification. Eur J Dermatol 2004

[9]. Nouri K, Ballard CJ, Patel AR, Brasie RA. Basal Cell Carcinoma. In: Nouri K, editor. Skin cancer. New York: Mc Graw Hill. 2007; $61-85$

Ro KW, Seo HS, Son WS, Kim HI. Subclinical Infiltration of Basal Cell Carcinoma in AsianPatients: Assessment after Mohs Micrographic Surgery. Ann Dermatol. 2011;23(3):276-81. 14: 272-5.

[10]. Dourmishev LA, Rusinova D, Botev I. Clinical variants, stages, and management of basal cell carcinoma. Indian Dermatol Online J 2013;4: 